\title{
Cortical mechanisms of unilateral voluntary motor inhibition in humans(Abstract_要旨)
}

$\operatorname{AUTHOR}(S)$ :

Taha Mina Begum

\section{CITATION:}

Taha Mina Begum. Cortical mechanisms of unilateral voluntary motor inhibition in humans. 京都大学, 2006, 博士(医学)

ISSUE DATE:

2006-03-23

URL:

http://hdl.handle.net/2433/143814

RIGHT: 
氏 名 Taha Mina Begum

学位(専攻分野) 博士 (医 学)

学位記番号医 博 第 2934 号

学位授与の日付 平 成 18 年 3 月 23 日

学位授与の要件学位規則第 4 条第 1 項該 当

研究科・専攻.医学研究科脳統御医科学系専攻

学位論文題目 Cortical mechanisms of unilateral voluntary motor inhibition in humans

（ヒトにおける随意性の一側性運動抑制の皮質機構）

論文調査委員 教授高橋良輔 教授河野憲二教授金子武嗣

\section{論 文 内 容 の 要 旨}

背景 正確な運動遂行には，筋収縮だけではなく，筋弛緩をも随意的に統御することが必要である。筋弛緩に関連した脳 活動の異常は, ジストニーなどの不随意運動を示す疾患で報告されている。これまでの磁気共鳴機能画像法や脳波・脳磁図 による研究によって，随意的な筋弛緩には，筋収縮と同様の反対側一次運動野の活性化が関連していることが報告されてい るが, その活性化がどのような生理的機構を介して筋弛緩を引き起こしているかは明らかではない。本研究では, 筋弛緩課 題遂行中に, 経頭蓋的磁気刺激法（Transcranial magnetic stimulation: TMS）を一次運動野に施行して, 興奮性と抑制性 の脳内機構の変化を検討した。

目的 随意的な筋弛緩の脳内機構を解明するために，右手内在筋の持続笳収縮を停止させるという課題を遂行中のヒト左 一次運動野の活動性変化を, 事象関連 TMS（単発刺激扔よび対刺激法）によって検討した。

対象及び方法 事前に文書での同意を得た健常ボランティア 9 名を被験者として実験を行った。実験課題には，視覚性の 対刺激 (S1, S2, 刺激間間隔 2 秒) を用いた遅延性反応課題を用いた（試行間間隔 $5-7$ 秒)。被験者は, 右第一背側骨間筋 （first dorsal interosseous muscle:FDI）で等尺性の弱収縮を持続し，試行ごとにランダムにモニター上に提示される S1 刺 激 (赤, 黄, 緑) の色に従って, あらかじめ指定された 3 種類の運動課題を $\mathrm{S} 2$ 刺激の直後に行った。運動課題として用い たのは，FDI 筋収縮の随意的停止 (筋弛緩課題)，FDI の弱収縮の継続 (NoGo 課題)，FDI の随意的強収縮（筋収縮課題） の3種類であった。課題遂行中の一次運動野の活動性の時間的変化を, TMS 単発刺激によって FDI に生じる運動誘発電位 の振幅および筋放電抑制の持続時間によって検討した。また，一次運動野での抑制性の活動をさらに詳細に評価するために， TMS による対刺激法（運動閾値下の刺激を用い，先行刺激に続いて刺激間間隔 2 ミリ秒で運動闘値上のテスト刺激を行う 刺激法で，先行刺激の存在による運動誘発電位の抑制を評価する）を用いて，皮質内抑制も計測した。

結果 個人間での反応時間の差を統制するために, フォース・トランスデューサで検知した運動（筋弛緩または筋収縮） の開始時点を基準として, データの事象関連解析を行った。筋弛緩課題では, 筋弛緩の開始21-70ミリ秒前に, 運動誘発電 位の低下と皮質内抑制の減少を認めたが，筋放電抑制時間には変化を認めなかった。筋収縮課題では，同じ時間帯で運動誘 発電位の増大と筋放電抑制時間の短縮を認めたが, 皮質内抑制の変化は明らかでなかった。NoGo 課題では, 計測した 3 種 のパラメータに変化を認めなかった。

考察 筋弛緩課題に関連して, 一次運動野での抑制性の活動は，变化なし（筋放電抑制）ないし減少（対刺激法による皮 質内抑制）していた。単発刺激法による筋放電抑制と対刺激法による皮質内抑制は，いずれもGABA 系の抑制性介在神経 細胞の活動に関連しているとされている。本研究において TMS で検討した範囲では, 随意的な筋弛緩には, 皮質内での抑 制性機構の関与は明らかでなかった。筋弛緩の中枢性機構としては, 皮質内での抑制以外に, 一次運動野から疽䯣の抑制性 介在神経細胞に投射する経路が知られている。本研究での随意的な筋驰緩には，この後者の経路が関与している可能性があ る。 
結論 随意的な筋弛緩は，一次運動野の活性化を伴う能動的な過程であることが報告されている。TMSを用いた検討に よって,この活性化が脊髄介在神経細胞を経由して筋放電を抑制する可能性があることが示唆された。

\section{論 文 審 查の 結 果 の 要 旨}

随意的な筇弛緩に関連して反対側一次運動野の活性化が認められるが，その生理的意義の詳細は知られていない。本研究 では，随意的筋弛緩の脳内機構を解明するために，右手内在筋の持続的筋収縮を停止させる課題を遂行中のヒト左一次運動 野の活動性変化を, 事象関連解析を用いた経頭蓋的磁気刺激法 (Transcranial magnetic stimulation:TMS)によって検討 した。被験者は筋の弱収縮を持続し, 視覚性の対刺激を用いた遅延性反応課題で, 筋収縮の停止・持続・強収縮の三種類の 課題のいずれかを行った。その反応時間の直前に与えたTMSによって一次運動野の興奮性と抑制性の機構を評価した。具 体的には，TMSによる運動誘発電位の振幅によって興奮性を評価し，筋放電抑制の持続時間と対刺激 TMSによる運動誘 発電位の抑制により皮質内抑制を推定した。筋弛緩の開始直前には運動誘発電位の低下と皮質内抑制の減少を認め, 強収縮 の直前には運動誘発電位の増大を認めたが皮質内抑制の変化は明らかでなかった。筋弛緩の中枢性機構としては，皮質内抑 制以外に一次運動野から沗䯣の抑制性介在神経細胞に投射する経路の存在が知られている。本研究での筋弛緩では皮質内抑 制はむしろ低下していたことから，随意的筋弛緩には後者の経路が関連している可能性が示唆された。

以上の研究は, 筋驰緩の随意的統御の解明に貢献し，運動過剩性の不随意運動などの運動異常症の発生機序を理解するた めの基䃈研究に寄与するところが多い。

したがって，本論分は博士（医学）の学位論文として価値あるものと認める。

なお，本学位授与申請者は，平成17年12月13日実施の論文内容とそれに関連した試問を受け，合格と認められたものであ る。 